\title{
Preparation and Quality Evaluation of Gluten-Free Biscuits
}

\author{
Simona MAN, Adriana PĂUCEAN*, Sevastiţa MUSTE \\ Faculty of Food Science and Technology, University of Agricultural Sciences and Veterinary Medicine, 3-5 \\ Mănăştur street, 3400, Cluj-Napoca, Romania \\ e-mail: adriana.paucean@usamvcluj.ro
}

Bulletin UASVM Food Science and Technology 71(1) / 2014

ISSN-L 2344-2344; Print ISSN 2344-2344; Electronic ISSN 2344-5300

\begin{abstract}
The aglutenics biscuits are intended to those persons who are suffering due to gluten intolerance, also named celiac disease. The fabrication technologies of the aglutenics products can be developed in on two ways: by separating the gluten from the grain or by replacing the grain flour with other types of gluten less flour, in case of bakery and pastry products. In this experiment, the gluten-free biscuits were obtained from the following flours mixture: maize flour (MF), rice flour (RF) and soybeans flour (SF). Other raw materials were used, such as: palmtree oil, honey, maize starch, eggs, sugar powdered, vanilla essence and sodium bicarbonate. Four experimental variants (gluten-free biscuits) were obtained by varying the proportion of flours ; these variants were coded as follows T1, T2 T3 and T4. The optimization of the aglutenics biscuits manufacture recipe was realized through sensory analyze, using the hedonic test ( 9 point scale). Samples of biscuits was subjected to the following physico-chemical analysis: moisture content, alkalinity, total carbohydrate content, total fat and protein content. Also the physical properties (length, width, thickness, weight and spread ratio) were determined in order to asses the blending influence on the biscuits quality. The blend with flour levels 30:30:40 (MF:RF:SF) led to the highest acceptability.
\end{abstract}

Keywords: gluten-free biscuits, manufacturing technology, sensory evaluation.

\section{INTRODUCTION}

Biscuits represent a fast growing segment of food because of consumer demands for convenient and nutritious food products. The consumers demand has increased for the quality food products with taste, safety, convenience and nutrition (Lubna Masoodi et al., 2012 ).

Biscuits are a popular foodstuff consumed by a wide range of population due to their varied taste, long shelf life and relatively low cost. Because of competition in the market and increased demand for healthy, natural and functional products, attempts are being made to improve the nutritive value of biscuits and functionality by modifying their nutritive composition. Such effects are very often achieved by increasing the ratio raw materials other than wheat or different types of dietary fibers in basic recipes with the attempt to increase biscuit's protein and mineral content for quality and availability (Tyagi et al., 2006, Lubna Masoodi et al., 2012) or increase dietary fiber content and improve prebiotic characteristics of the final product (Gallagher et al.,2003, Lubna Masoodi et al., 2012 ).

Celiac disease or gluten sensitive enteropathy is a chronic disorder of the small intestine caused by exposure to gluten in the genetically predisposed individuals (Laurin et al., 2002; Hamer, 2005, Ahmed M.S. Hussein et al.,2012). It is characterized by a strong immune response to certain amino acid sequences found in the prolamin fractions of wheat, barley and rye (Hill et al., 2005, Ahmed M.S. Hussein et al.,2012). When people with celiac disease eat foods or use products containing gluten, 
their immune system responds by damaging or destroying the intestinal villi leading to the malabsorption of nutrients, thus adversely affecting all systems of the body (Feighery, 1999, Ahmed M.S. Hussein et al.,2012). Intestinal symptoms can include diarrhea, abdominal cramping, pain and distention and untreated celiac disease may lead to vitamin and mineral deficiencies, osteoporosis and other extra intestinal problems. The gluten-free diet remains until now the only treatment for celiac disease. Gluten free diet has benefits such as the recovery of the villi of the small intestine and risk reduction of malignant complications (Seraphin \& Mobarhan, 2002, Ahmed M.S. Hussein et al.,2012). As per rule the "Gluten free" is a voluntary term and defined as food containing less than $20 \mathrm{ppm}$ of gluten. The gluten is a protein complex found in the triticeae tribe of wheat, barley (Hordeum vulgare) and rye (Secale cereale), which provides desirable organoleptic properties (texture and taste) to many bakery and other food products. Gluten is known as "heart and soul" of bakery for providing the processing qualities familiar to both the home baker as well as the commercial food manufacturer. Since gluten plays a limited role in defining the processability and end product quality of biscuits, it can be complemented through some alternate flours in various combinations (Sweta Rai et al., 2011).

The aim of the present work was to test rice flour (RF), maize flour (MF) and soybean flour (SF) for the development of gluten-free biscuits targeting a good sensory acceptance and good nutritional value.

\section{MATERIALS AND METHODS}

\section{Procurement of raw materials}

In order to prepare the biscuits, the following materials has been purchased from local market: maize flour (MF), rice flour (RF), soybean flour (SF), palmtree oil, honey, maize starch, eggs, powdered sugar, vanilla essence, sodium bicarbonate.

\section{Experimental plan}

The experimental plan used for the present research is given in Table 1 and Figure 1 shows the flow chart for the biscuits preparation. Table 2 shows the different combination of maize flour, rice flour and soybean flour, while the ingredients used in the preparation of biscuits (in g) are presented in Table 3.

Table 1. Experimental Plan

\begin{tabular}{cccc}
\hline S. No & Parameter & Level & Description \\
\hline 1. & Product & 1 & Biscuit \\
\hline 2. & Ingredients & 10 & $\begin{array}{c}\text { Maize flour, rice flour, soybeans flour, palm } \\
\text { tree oil, honey, maize starch, eggs, sugar } \\
\text { powdered, vanilla essence and sodium } \\
\text { bicarbonate }\end{array}$ \\
\hline 3. & Samples & 4 & $\mathrm{~T}_{1}, \mathrm{~T}_{2} \mathrm{~T}_{3}$ and $\mathrm{T}_{4}$ \\
\hline 4. & Analysis & 3 & $\begin{array}{c}\text { Physico- chemical analysis (5), sensory } \\
\text { analysis (5), physical analysis (4) }\end{array}$ \\
\hline 5. & Packaging material & 1 & HDPE \\
\hline 6. & Storage condition & 1 & Ambient temp \\
\hline
\end{tabular}

Table 2. Treatments descriptions. Different combination of maize flour, rice flour and soybeans flour for biscuits manufacturing

\begin{tabular}{cccc}
\hline Treatment & Maize flour (MF), \% & Rice flour (RF), \% & Soybean flour (SF), \% \\
\hline $\mathrm{T}_{1}$ & 33.33 & 33.33 & 33.33 \\
$\mathrm{~T}_{2}$ & 32 & 42 & 26 \\
$\mathrm{~T}_{3}$ & 30 & 30 & 40 \\
$\mathrm{~T}_{4}$ & 26 & 37 & 37 \\
\hline
\end{tabular}




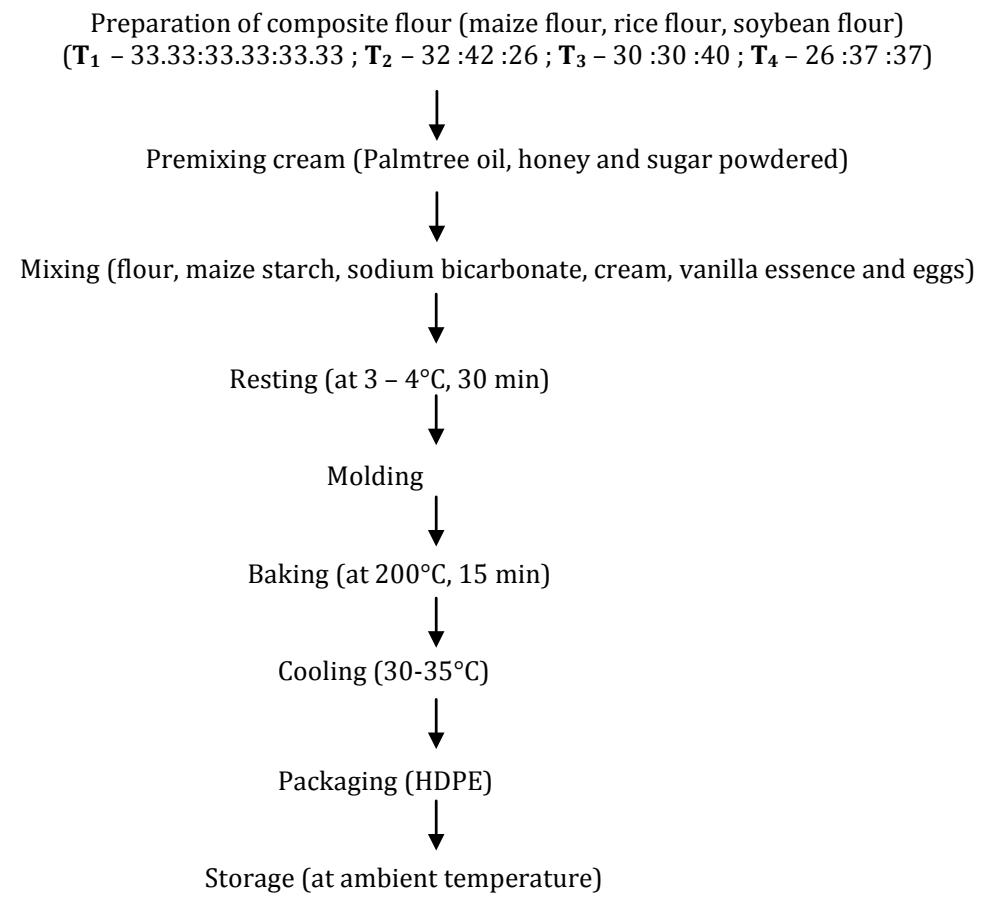

Fig. 1. Flow chart for gluten-free biscuits preparation

Table 3. Ingredients used in the preparation of biscuits (in g)

\begin{tabular}{cccccc}
\hline S. No & Ingredients & $\mathbf{T}_{1}$ & $\mathbf{T}_{2}$ & $\mathbf{T}_{\mathbf{3}}$ & $\mathbf{T}_{4}$ \\
\hline 1. & $\mathrm{MF}$ & 33.33 & 32 & 30 & 26 \\
\hline 2. & $\mathrm{RF}$ & 33.33 & 42 & 30 & 37 \\
\hline 3. & $\mathrm{SF}$ & 33.33 & 26 & 40 & 37 \\
\hline 4. & Maize starch & 5 & 5 & 5 & 5 \\
\hline 5. & Eggs & 40 & 40 & 40 & 40 \\
\hline 6. & Honey & 27 & 27 & 27 & 27 \\
\hline 7. & Sugar powdered & 17 & 17 & 17 & 17 \\
\hline 8. & Palm tree oil & 20 & 20 & 20 & 20 \\
\hline 9. & Vanilla essence & 9 & 9 & 9 & 9 \\
\hline 10 & Sodium bicarbonate & 8 & 8 & 8 & 8 \\
\hline
\end{tabular}

\section{Physical evaluation of gluten-free biscuits}

Width and length: Six biscuits were placed edge to edge and their total width was measured with a vernier caliper ( $0.01 \mathrm{~mm}$ accuracy). The average width was determined by taking the mean value (Nouma R. Siddiqui et al., 2003). Similarly the biscuits length was determined by placing the butt of six biscuits and taking the mean value.

Thickness was measured by stacking six biscuits on top of each other and taking average thickness $(\mathrm{cm})$.

Weight of biscuits was measured as average of values of four individual biscuits with the help of digital weighing balance.
Spread ratio was calculated by dividing the average value of width by average value of thickness of biscuits by the method of Akubor P.I. et al., 2003, using the following formula:

$$
\begin{aligned}
& S F=W / T \\
& \text { W - width biscuits }(\mathrm{cm}) \\
& \mathrm{T} \text { - thickness biscuits }(\mathrm{cm})
\end{aligned}
$$

Volume of biscuits was calculated using length (L), width (W) and thickness (T) using the following formula: 
$\operatorname{volume}\left(\boldsymbol{m}^{3}\right)=L \times W \times T$

$\mathrm{L}=$ average length of biscuits $(\mathrm{cm})$

$\mathrm{W}=$ average width of biscuits $(\mathrm{cm})$

$\mathrm{T}=$ average thickness of biscuits $(\mathrm{cm})$

Density: After calculating volume, density was obtained from the ratio between weight and volume (Sneha Srivastava et al. 2012).

$$
\operatorname{density}\left(\frac{g}{\boldsymbol{m}^{3}}\right)=\frac{\operatorname{Weight}(g)}{\operatorname{volume}\left(\boldsymbol{m}^{3}\right)}
$$

\section{Chemical characteristics}

The moisture, alkalinity, fat and total carbohydrates content were determined according to STAS 1227-3/1990. Protein content was determined by using Kjeldhal Method and the conversion factor 5.7 .

\section{Sensory evaluation}

Biscuits were evaluated for overall acceptability (texture, colour, taste, odor and aroma) and the sensory evaluation was carried out as per 9 point Hedonic scale; the panell was formed by ten semi trained judges. In Figure 2, the four samples of the gluten-free biscuits are presented.
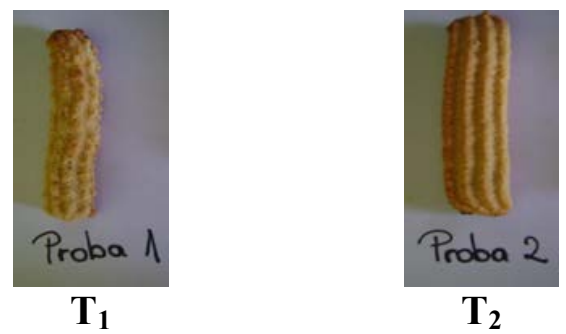

\section{RESULTS AND DISCUSSION}

Physical analysis of gluten-free biscuits

The results of the physical analysis for aglutenic biscuits produced from maize, rice and soybean flour blends is shown in Table 4. The length, width, thickness, weight and spread ratio did not differ significantly ( $p>0.05)$. These results are supported also by the experimental baking studies (data not shown) which indicated that different levels of SF, RF and MF did not adversely affect the handling properties of the doughs.

The weight ranged between $8.4 \mathrm{~g}$ and $8.2 \mathrm{~g}$ for biscuits made from the MF, RF and SF in different level. The width of biscuit decreases from 1.95 to $1.85 \mathrm{~cm}$ with increasing in the level of rice flour. The result shows that treatment $\mathrm{T} 2$ has the maximum width $1.95 \mathrm{~cm}$, followed by T4 (1.90) and T3 (1.88) while minimum width was observed in T1 (1.85).

The biscuits thickness increases from 0.68 to $0.72 \mathrm{~cm}$ with increasing level of soy flour in the blend (Tab. 4). The results show that $\mathrm{T} 3$ has maximum thickness $0.72 \mathrm{~cm}$ followed by $\mathrm{T} 4(0.70 . \mathrm{cm})$ and T1 $(0.68 \mathrm{~cm})$ while minimum width was observed in T2 $(0.65 \mathrm{~cm})$. The spread factor of biscuits decreases from 3.00 to $2,61 \mathrm{~cm}$ with increasing the level of soy flour. We consider that the spread ratio value is influenced by the competition of flours, especially SF and RF, for the available water. In this situation the dough viscosity is increased and the

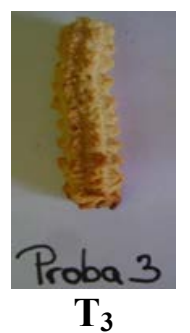

Fig. 2. Photos of biscuits made from composite flours obtained by mixing MF, RF and SF in different proportions

Table 4. Physical properties of biscuits

\begin{tabular}{cccccc}
\hline $\begin{array}{c}\text { Biscuits } \\
\text { Samples }\end{array}$ & $\begin{array}{c}\text { Length } \\
(\mathbf{c m})\end{array}$ & $\begin{array}{c}\text { Width } \\
\mathbf{( c m )}\end{array}$ & $\begin{array}{c}\text { Thickness } \\
(\mathbf{c m})\end{array}$ & Spread ratio & $\begin{array}{c}\text { Weight } \\
(\mathrm{g})\end{array}$ \\
\hline $\mathrm{T}_{1}$ & 9.8 & 1.85 & 0.68 & 2.72 & 8.4 \\
\hline $\mathrm{T}_{2}$ & 9.7 & 1.95 & 0.65 & 3.00 & 8.4 \\
\hline $\mathrm{T}_{3}$ & 10.0 & 1.88 & 0.72 & 2.61 & 8.3 \\
\hline $\mathrm{T}_{4}$ & 9.8 & 1.90 & 0.70 & 2.71 & 8.2 \\
\hline
\end{tabular}

*Data represents means of three determinations 
spread ratio is higher. SF and RF had a higher water absorption capacity than MF.

Claughton and Pearce, 1989, reported a reduction in spread ratio of cookies by increasing the enrichment levels of sunflower protein isolates, Akubor P.I. and Onimawo I.A., 2012, by increasing the enrichment levels with soybean flour and Neha Mishra and Ramesh Chandra, 2012 reported a reduction in spread ratio of biscuits by increasing the enrichment levels with soy flour and rice bran..

Figure 3 - 4 show the effect of treatments on volume and density of gluten free biscuits. The volume of gluten free biscuits increased linearly with increasing addition of soy flour whereas, density decreased in the similar manner. This may be due to higher protein content in the soy flour.

\section{Chemical analysis of gluten-free biscuit}

During the present research no significant difference was found in the moisture content and alkalinity. The moisture content of the sample biscuits ranged between $10.15 \%$ and $10.85 \%$, while the alkalinity, expressed as degree, ranged between 11.6 and 12.2. The total carbohydrates content ranged between $13.6 \%$ to $14.5 \%$. The protein content ranged from $18.03 \%$ to $21.00 \%$, while the fat content varied from $13.56 \%$ to $20.35 \%$; these values are within the acceptable limits for biscuits given by the Romanian settlement STAS 1227-3/90. (Fig. 5 - 8). Significant changes in the biscuits protein and fat values were recorded related to the increment of the soy flour content in the recipe. Soybean flour has a moisture content close to the rice flour and corn flour, but high fat and protein content. Therefore, a significant difference was observed between the samples. The protein and fat content of biscuits increased linearly with the increase in soybean flour addition. These results are consistent with those reported by Noah Mishra and Ramesh Chandra, 2012, and Akbar P.I. et al., 2003.

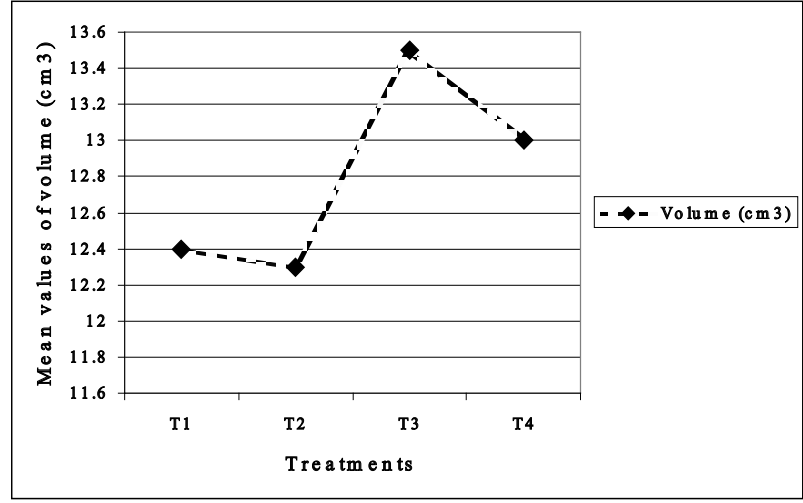

Fig. 3. Effect of treatments on volume o f gluten free biscuits

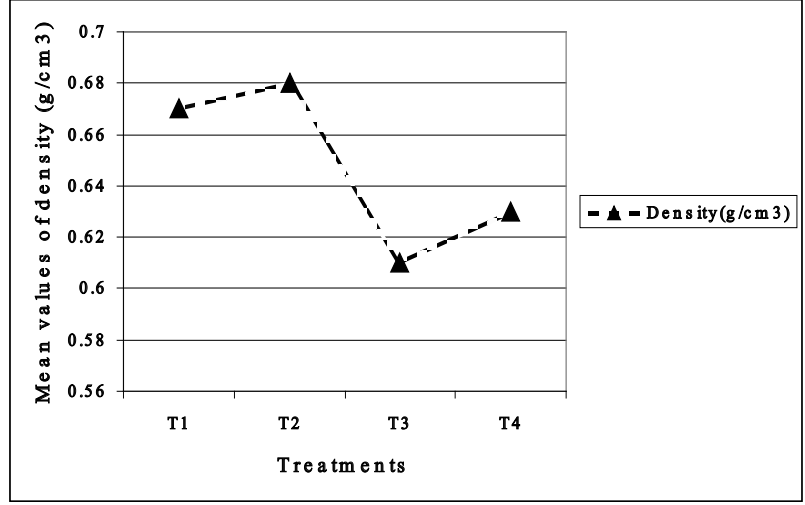

Fig. 4. Effect of treatments on density of gluten free biscuits

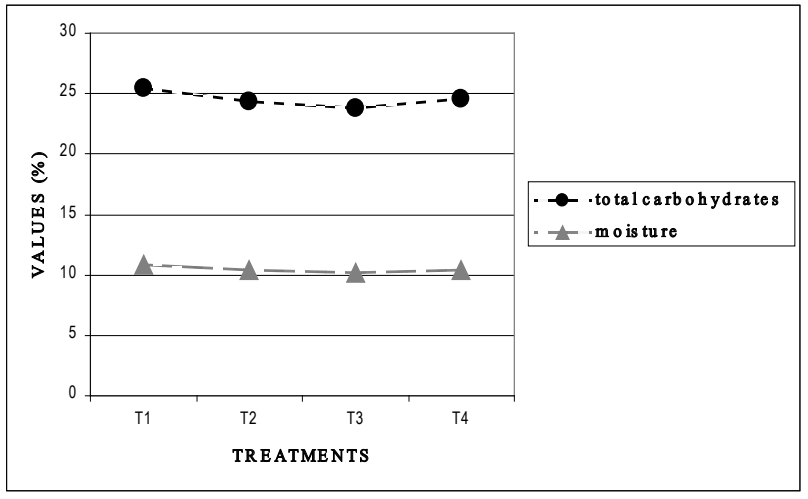

Fig. 5. Effect of flours blending on moisture and total carbohydrates content of gluten-free biscuits 
Sensory evaluation for gluten-free biscuit

The Sensory evaluation was carried out as per 9 point Hedonic scale Table 4. The sensory attributes that were taken into consideration include: texture, colour, taste, odor and aroma. The values are the means of ten readings. Among the four samples, the third sample (30:30:40) recorded the highest acceptability.

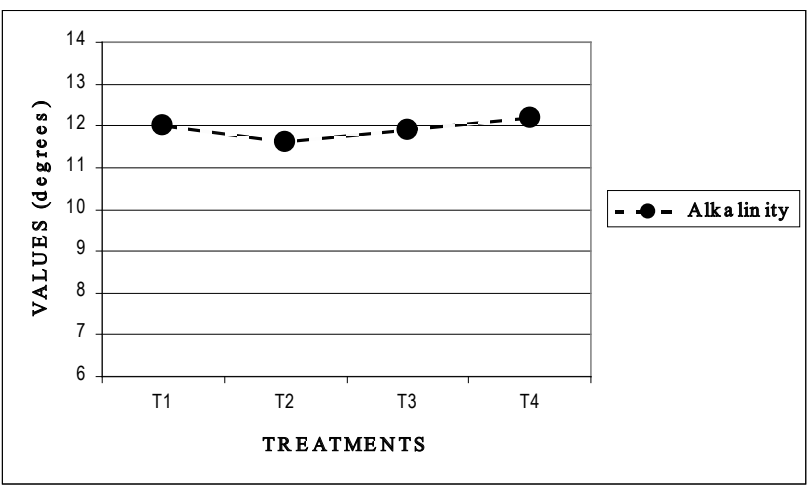

Fig. 6. Effect of flours blending on alkalinity of gluten-free biscuits

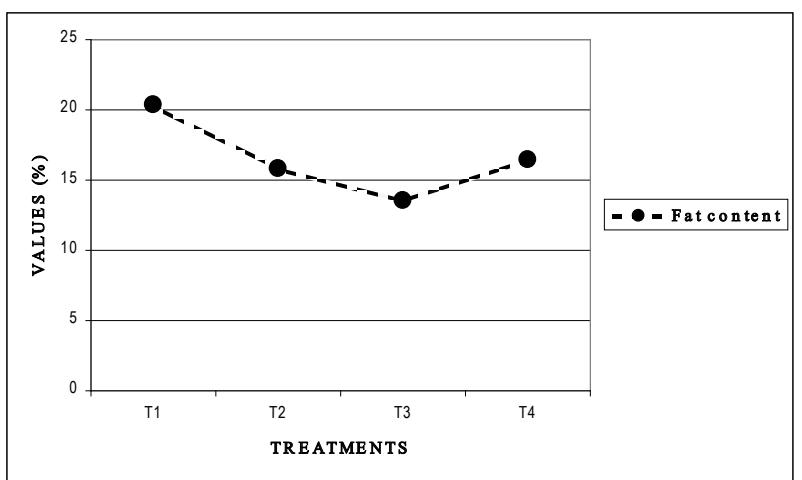

Fig. 7. Effect of flours blending on fat content of gluten-free biscuits

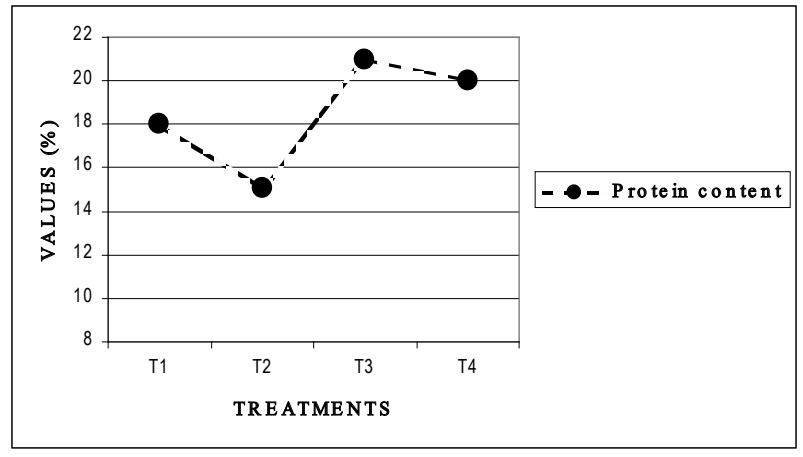

Fig. 8. Effect of flours blending on protein content of gluten-free biscuits

Table 5. Sensory scores of prepared gluten-free biscuits using different blends (MF:RF:SF)

\begin{tabular}{cccccc}
\hline Treatments & Colour & Texture & Taste & Odor & Aroma \\
\hline $\mathrm{T}_{1}$ & 8.3 & 8.6 & 8.4 & 8.5 & 8.3 \\
\hline $\mathrm{T}_{2}$ & 8.3 & 8.7 & 8.0 & 8.1 & 7.8 \\
\hline $\mathrm{T}_{3}$ & $\mathbf{8 . 3}$ & $\mathbf{8 . 8}$ & $\mathbf{8 . 7}$ & $\mathbf{8 . 7}$ & $\mathbf{8 . 5}$ \\
\hline $\mathrm{T}_{4}$ & 8.0 & 7.8 & 7,6 & 7.6 & 7.4 \\
\hline
\end{tabular}

*Data represents means of three determinations 


\section{CONCLUSION}

It is evident from the experiment that gluten-free biscuits can be made by mixing different non-wheat flours such as: rice flour, maize flour and soy flours. This type of biscuits are useful in the gluten-free diets therefore require good nutritional and sensory quality.

The blend consisting of MF30: RF30: SF40\% was successfully used for gluten-free biscuits preparation without adversely affecting the physical and the sensory characteristic of biscuit. Addition of soy flour up to $40 \%$ leads to biscuits with good nutritional and sensorial properties.

\section{REFERENCES}

1. Ahmed, M.S. et al. (2012). Production and Evaluation of Gluten-Free Cakes, Australian Journal of Basic and Applied Sciences, 6(12): 482-491.

2. Akubor, P.I. and Ukwuru, M.U. (2003). Functional properties and biscuit making potential ofsoybean and cassava flour blends, Plant Foods for Human Nutrition 58:1-12.

3. Baljeet, S.Y. et al. (2010). Studies on functional properties and incorporation of buckwheatflour for biscuit making, International Food Research Journal 17:1067- 1076.

4. Claughton, S.M. and Pearce, R.J. (1989). Protein enrichment of sugar-snop cookies with sunflower protein Isolate, J Food Sci 54:354-356.

5. Schamne, C. et al. (2010). Obtention and characterization of gluten-free baked products, Ciênc. Tecnol. Aliment., Campinas, 30(3): 741-750.

6. Awasthi, I. et al. (2012). Development of soy fertified high protein and high calorie supplementary biscuits, Indian J.Sci.Re4s.3 (1):51-58.
7. Naseem, K. et al. (2013). Development, Characterization And Evaluation Of High Energy Biscuits For Combating Malnourishment Amongchildren In Pakistan, Pakistan J. Agric. Res. 26(3):230-236.

8. Masoodi, L. and Bashir, V. A. K. (2012). Fortification of Biscuit with Flaxseed: Biscuit Production and Quality Evaluation, Journal Of Environmental Science, Toxicology And Food Technology, 1: 6-9.

9. Neha, M. and Ramesh, C. (2012). Development of functional biscuit from soy flour \&rice bran, International Journal of Agricultural and Food Science 2(1): 14-20.

10. Aziah, N. A.A. and Komathi, C.A. (2009). Acceptability attributes of crackers made from different types of composite flour, International Food Research Journal 16:479-482.

11. Nouma, R. S. et al. (2003). Sensory amd physical evaluation of biscuits suplplemented with soy flour, Pak J. Food, 13 (1-2): 45-48.

12. Srivastava, S. et al. (2012). Preparation and Quality Evaluation of Flour and Biscuit from Sweet Potato, J Food Process Technol p. 1-5, http:// dx.doi.org/10.4172/21577110.1000192.

13. Kumar, S. R. and Lalan, K. S. (2010). Evaluation of quality characteristics of soy based millet biscuits, Advances in Applied Science Research, 1 (3):187-196.

14. Srivastava, S. et al. (2012). Preparation and Quality Evaluation of Flour and Biscuit from Sweet Potato, J Food Process Technol 3:192. doi:10.4172/21577110.1000192

15. Rai, S. et al. (2011). Quality characteristics of gluten free cookies prepared from different flour combinations, J Food Sci Technol DOI 10.1007/s13197-011-0547-1.

16. Seevaratnam, V. et al. (2012). Studies on the Preparation of Biscuits Incorporated with Potato Flour, World Journal of Dairy \& Food Sciences 7 (1):79. 